\title{
Causal uncertainty, joint and several liability and insurance
}

Citation for published version (APA):

Faure, M. G. (2003). Causal uncertainty, joint and several liability and insurance. In H. Koziol, \& J. Spier (Eds.), Liber Amicorum Pierre Widmer (pp. 79-98). Springer.

Document status and date:

Published: 01/01/2003

Document Version:

Publisher's PDF, also known as Version of record

\section{Please check the document version of this publication:}

- A submitted manuscript is the version of the article upon submission and before peer-review. There can be important differences between the submitted version and the official published version of record.

People interested in the research are advised to contact the author for the final version of the publication, or visit the DOI to the publisher's website.

- The final author version and the galley proof are versions of the publication after peer review.

- The final published version features the final layout of the paper including the volume, issue and page numbers.

Link to publication

\footnotetext{
General rights rights.

- You may freely distribute the URL identifying the publication in the public portal. please follow below link for the End User Agreement:

www.umlib.nl/taverne-license

Take down policy

If you believe that this document breaches copyright please contact us at:

repository@maastrichtuniversity.nl

providing details and we will investigate your claim.
}

Copyright and moral rights for the publications made accessible in the public portal are retained by the authors and/or other copyright owners and it is a condition of accessing publications that users recognise and abide by the legal requirements associated with these

- Users may download and print one copy of any publication from the public portal for the purpose of private study or research.

- You may not further distribute the material or use it for any profit-making activity or commercial gain

If the publication is distributed under the terms of Article $25 \mathrm{fa}$ of the Dutch Copyright Act, indicated by the "Taverne" license above, 


\section{Causal Uncertainty, Joint and Several Liability and Insurance}

Michael Faure

\section{Table of Contents}

I. Introduction

II. Shifting the Risk of Causal Uncertainty

A. Examples

B. Economic Analysis

1. Four Options

2. All or Nothing

3. Probability of Causation

4. Threshold Liability

5. Proportionate Liability

6. Nuances

C. Insurability

III. Joint and Several Liability
A. Examples
B. Economic Analysis
C. Insurability

IV. Channeling of Liability
A. Examples
B. Economic Analysis
C. Insurability

V. Concluding Remarks

\section{Introduction}

Pierre Widmer has always shown a great interest in a search for the limits of liability law in his many publications. In his publications on product liability, environmental liability and more particularly in his work on the reform of tort law in Switzerland, Pierre Widmer has always shown a great concern for, on the one hand, the justified interests of the victim seeking compensation of his loss, but, on the other hand, also for enterprises being exposed to an increasing expanding liability. Also during his participation at the meetings of the European Group on Tort Law, Pierre Widmer has shown a concern for an expanding scope of liability whereby the reasonable limits of such a liability would be trespassed upon. One of the concerns he has often expressed is that this expanding scope of liability might also endanger the insurabillity of the liability risk. It is precisely this relationship between tort liability and insurability that I would like to address in this contribution to honour Pierre. 
The issue that I would like to address in this contribution is increasingly receiving attention in the literature and has also been dealt with by the European Group on Tort Law of which Pierre Widmer is such a prominent member, being the effects of uncertainty concerning the causal relationship.' In case of scientific uncertainty concerning the relationship between e.g. a certain industrial activity on the one hand and (health) damage on the other hand, one can distinguish an increasing tendency in tort law, more particularly in case law, to hold the effects of this uncertainty against the injurer. This can take various legal forms. In some cases full scientific proof of a causal relationship is simply not required; in other cases the doubt concerning the causal relationship will result in a reversal of the burden of proof. These issues play a role in several areas of tort law but more particularly in areas of environmental and health risks. The issue deals with fundamental questions of tort law, being where risks should be allocated in case of uncertainty, in this case concerning the causal relationship. Often much of our sympathy in this respect is - understandably - with the victim. Therefore, it is (explicitly or implicitly) often held that the one who should bear the risk of this uncertainty should be the injurer and not the victim. However, the consequences (also economic) of such a seemingly victim friendly approach may be devastating. Suppose that one established that, in the neigliborhood of a certain factory, the amount of cancer cases is higher than the country average and suppose that one also accepted that this increased risk of getting cancer might be due to the presence of the factory, but that it cannot be established which of the many cancers in the neighbourhood are caused by the presence of the factory. A reversal of the burden of proof or a shift of the risk of causal uncertainty would then mean that the factory would have to pay for the consequences of all the cancers in the neighbourhood, in other words also for the background risk, whereas it may only have caused the additional cancers, in other words the excess risk. This simple example already shows that simple rules like shifting the risk of causal uncertainty or reversals of the burden of proof to the injurer may be too unbalanced and may have as effect that enterprises will then have to bear financial consequences of risks which have not been caused by them at all.

The crucial question is therefore whether it is possible to fine-tune tort law in such a way that injurers are only held liable for the risks they actually cause. Shifting the risk of causal uncertainty to the injurer would indeed be a deviation of this rule. There are, moreover, many more examples of similar situations. Think for instance of the tendency to hold several liortfeasors jointly and severally liable when it cannot be established which of the many torteasors actually caused the loss or think about the tendency in international conventions to channel the risk to one of the many potential injurers. In all of those cases, the risk exists that one injurer is held to pay for consequences of losses that he may not have caused. Undoubtedly from a legal perspective there may be good reasons for such an approach (more particularly the wish to protect the innocent victim), but one can equally question whether it is just

'A topic which has also been addressed by the Group. See the various contributions in J. Spier (ed.), Unification of Tort Law: Causation (2000). 
and efficient to hold injurers liable to pay for damage which they have never caused. Moreover, this tendency to expand the scope of tort law in such a way that injurers can also be held to pay for losses which they have not caused themselves, may hawe dramatic consequences for the insurability. This brings us to the central idea of this contribution for Pierre Widmer. If tort law were to expand in such a way that injurers are held liable also for risks that they have not caused themselves, simply stated it would also mean that their liability insurers are held to compensate for risks that have not been caused by their insured and for which therefore no premium has been paid, and no reservations have been set aside. The question therefore arises whether these tendencies in rort law may endanget the insurability of certain risks.

I would like to address this issue by dealing with a number of situations which have as common denommator that the danger exists that the injurer (and therefore his liability insurer) nay be held to compensate for more losses than the actual damage which was caused by his activity. This danger may ex ist in case of a shifting of the risk of causal uncertainty (par. 2), but also in case of joint and several liability (par. 3) or with a channelling of the liability (par. 4).

I am well aware that Pierre Widmer does not believe in the fundamental principle of the economic analy sis of law, being that tort law should be seen as an instrument to deter certain undesirable activities. Pierre told me at many occasions that he is not a believer in the preventive effect of tort law. Nevertheless, $I$ am going to use the economic analysis of law particularly because this is a usefull tool to show some of the consequences of expanding liability for the insurability of these risks. I hope that, at this stage, I may convince Pierre that even for the non-believers of the deterrent effect of tort law, law and economics is at least useful since it can provide some insights in insurability-issues.

Let us start with the first example, shifting the risk of causal uncertainty.

\section{Shifting the Risk of Causal Uncertainty}

\section{A. Examples}

Many examples exist in tort law of situations where there is uncertainty conceming the causal relationship between the tort and the damage. ${ }^{2}$ There are a few cases which have risen in Dutch tort law which provide good illustrations of the problems that can arise in case of uncertainty conceming the causal link.

The first example concerns the drug DES. This product caused birth defects and certain daughters of mothers, who took DES during pregnancy, suffered physical harm. The causal link between the use of DES by the mother and the daughter's symptoms was not disputed. It was also known that certain manufacturers had brought DES onto the market. However, uncertainty ex-

See on this topic also the many publications of Akkermans and more particularly his dissertaton A. Akkermans, Proportionele anansprakelijkine do bij onzeker causaal verband (1997). 
isted with respect to which manufacturer had sold a specific product to a particular mother. Several "DES daughters" sued some of the producers that had brought DES onto the market at the time, although they could not prove from which manufacturer their mother had bought the drug. This gave rise to a lengthy debate about whether some sort of proportionate liability rule should be applied to apportion the burden of liability between the manufacturers. A market-share liability would be an example of such a proportionality rule. The Dutch Supreme Court, however, applied a so-called "alternative causation" rule, meaning that the DES daughters are allowed to claim full compensation from any of the manufacturers. ${ }^{3}$ A manufacturer can still rebut the presumption by proving that he did not sell DES to the particular mother, but this will often be impossible in practice. ${ }^{4}$ Hence, this result is similar to a joint and several liability rule. ${ }^{5}$

A second example of shifting the burden of causal uncertainty relates to the employer's liability for occupational diseases. In a well-known Supreme Court case, Cijsouw v. De Schelde, a victim of asbestosis could not prove at what time he had been in contact with the fatal asbestos fibre that caused his disease. The determination of this moment was crucial for the case since Cijsouw had worked for the defendant firm for several years, but initially the employer could not have known that he had to take measures to protect his employee against asbestos and thus could not be liable. The Supreme Court once more shifted the risk of uncertainty concerning causation to the enterprise by holding that it was presumed that the employee had been in contact with the fatal asbestos fibre during the second period of his employment with the defendant. ${ }^{6}$ This presumption could have been rebutted if the defendant had been able to prove that it was not during the second period of their employing $\mathrm{Cij}$ souw that the latter was in contact with the fatal fibre. ${ }^{7}$ Obviously, this would have been practically impossible for the employer.

In both cases there is some causal uncertainty whereby the burden of proof is shifted to the enterprise. Since causation issues are very often difficult to prove with scientific certainty, this shift in the burden of proof will often be decisive for the outcome of the case. Legal systems, other than that of the Netherlands, have been confronted with the consequences of causal uncer-

3. For a discussion of allernative causation under German law, see J. Köndgen. Multiple causation and joint tortfeasors pollution cases according to German law, in: J. M. van Dunnê (ed.). Transw boundary Pollution and Liability, the Case of the River Rhine (1991), pp. 99-106, and the interesting article of Th. Bodewig, Probleme alternativer Kausalitäit bei Massenschäden, [1985] Archin fin wie crillistische Praxis (AcP), 505-558.

"Note, however, that the Dutch Supreme Court only considered the causation question. Forntrally, it still has to be decided whether bringing DES on the market was in itself wrongful. See Hoge Raad 9 October 1992, [1994] Nederlandse Jurisprudentie (NJ), 535 (C.J.H.B.). See on this case, J. Spiet/J. H. Wansink, Joint and Several Liability of DES Manufacturers: A Dutch Ton Crisis. [1993] International Insurance Law Review (ILLR), 176-181.

"So J. Spier in J. Spier (ed.). The Limits of Liability, Keeping the Floodgates Shut (1996), pp. 123-124. For a critical economic analysis of jount and several liability, see T. H. Tietenberg, Indivisible toxic torts: the economics of joint and seweral liability, 1989] Land Economics 65 , $305-319$ and see below 3B.

J. Spier (supra note 5), pp. 124-125.

"Hoge Raad 25 June 1993, [1993] NJ, 686. 
tainty as well. This plays a special role in the so-called toxic torts, ${ }^{\text {whereby }}$ some of the population have been exposed to hazardous substances or radiation and subsequently a certain disease, such as cancer, is discovered. The problem is that, unfortunately, people do get this particular disease, cancer, from various sources. So the identity of the injurer is certain, but there is uncertainty about who the victim is. Indeed, they may well have got the disease from some background risk and not from the presence of, say, a nuclear power plant." Such questions have indeed arisen both in Belgium and in the United Kingdom. Causal uncertainty played a role in the famous British Sellafield case, where an English court had to decide on the causal relationship between childhood leukaemia and the nearby presence of a nuclear power plant at Sell. afield. ${ }^{10}$ Similarly, Belgian courts have been confronted with the question of whether the physical complaints of inhabitants of the community of Mellery in the Walloon Region were caused by emissions from a nearby waste site."

\section{B. Economic Analysis}

\section{Four Options}

These cases show that the crucial question arises how the law should deal with causal uncertainty. We assume here that various expert opinions exist on the likelihood that a certain activity may cause a certain damage and that this scieniffic expertise results in a probability, expressed in a percentage. Thus, experts could judge that it is unknown whether a certain drug or activity may cause a certain health disease, but could establish that there is e.g a $30 \%, 50 \%$ or $70 \%$ probability that this is the case. The question then obviously arises how, within the legal system, one should deal with this uncertainty if expert opinion cannot prowide certainty on causation. In this hypothesis, we assume that scientists agree that there is a likelihood (of approx. 30\%) that a certain activity causes a certain damage, but no absolute scientific certainty. The question then arises how the law should deall with this information. In fact, four options exist:

- one could, on the one hand, judge that as soon as there is any statistical chance that a certain activity (or product) may cause a certain damage, all victims receive $100 \%$ compensation of their clamage;

- the second possibility is to refuse the claim of the victim unless there is $100 \%$ certainty that the tort caused the damage;

5. I. Trauberman, Statutory reform of 'toxic torts'. Relieving legal, scientific and economic burdens on the chemical victim, [1983] Harvard Enviwomental Law Review (HELR), 177-296.

* Estep. Radiation injuries and statistics: the need for a new approach to injury litigation, [1960] Michigan Law Review (MLR), 259-304; A. Van, Statistisch bewigs van causad warband. Discussion of High Courr of Justice 8 October 1993 (Sellafield Clains), [1994] Tujdschriff voor Milver Aansprakelijkheid. (TMA), $109-118$ and A. Vam, Onzekerhe "dover daderschap en cansaliteit $(1995)$, pp. 145m-154.

19. Gardner, Results of a case-control study of leukaemiat and lymphoma among young people near Sellafield nuclear plant in West Cumbria, 11990] British Medical Journal, 423-434.

$"$ For a discussion of that case see L. Lavrysen, Judicial responses in the nimeties to Dutch (and German) shipments of waste to Belgium in the eighties, [1995] Macasticht Joural of European and Comparaive Low (MD), 219-243. 
- the third possibility is to award compensation only when the probability that the damage was caused by the tort passes a certain threshold of, say, $50 \%$. This threshold rule is a kind of "all or nothing" approach: if the probability is lower than the threshold, the victim receives no compensation at all; if the probability is higher than the threshold, the victim receives full compensation. This threshold rule is known in the American literature as the "more probable than not" solution, referring to the fact that the plaintiff must convince the judge that it is "more probable than not" that its damage was caused by the tort;

- the final solution is to take into account the probability that the tort caused a certain damage and to award compensation, taking into account this probability. This would mean that if the scientific expertise indicates that the likelihood of damage is, say, $40 \%$ that the victim can then receive compensation for $40 \%$ of his damage.

The way the law should deal with causal uncertainty has been addressed extensively in the economic literature, for instance by Rosenberg ${ }^{12}$, Kaye ${ }^{13}$ and Shavell. ${ }^{14}$ This literature provides some interesting insights concerning the question of how to deal with cases of causal uncertainty like the ones discussed above. Shavell indicates that there is a good economic reason to limit the liability of the injurer to the damage that he has actually caused. If the requirement of the causal link did not have this limiting effect, a consequence could be that, especially in cases of strict liability, a potential injurer (e.g. an enterprise) could abstain from activities which are as such socially useful and therefore desirable (such as e.g. the production of pharmaceuticals). A potential liability for damage which has not been caused through the influence of the injurer would thus be considered as "crushing".15

\section{All or Nothing}

Let us address more closely the various options addressed above. The first option would be to award a victim total compensation of damage, even if the probability that his loss was actually caused by the injurer"s activity was relatively low, say $30 \%$. In such a case, this means that we also know that there is a $70 \%$ probability that the damage (e.g. a certain illness) was caused through another event. If an injurer is held liable for the full amount even if there was. only a $30 \%$ probability that his activity caused a loss, this will lead to too few

13 D. Rosenberg, The causal connection in mass exposure cases: "public law" vision of the tort system, [1984] Harvard Law Review (HLR), 851-929.

II D. Kaye, The limits of the preponderance of the evidence standard: justifiably naked statistical evidence and multiple causation, [1982] American Bar Foundarion Research Journal, 487-516 and see S. Gold, Causation in toxic torts: burdens of proof, standards of persuasion, and statisthical evidenee. [1986] Wale Law Jowrmal (YLJ). 376-402.

is. Shavell, Uncertainty over causation and the determination of civill liability, [ [1985] Journol of Law and Econowic (JLE), 587-609.

1.5 See S. Shavell. Economic anabysis of accident law (1987), p. 108; a sintilar point is made by M.J. Trebilcock. The social insurance - deterrence dilemma of modern North American tord law: a Canadian perspective on the liability insurance crisis, [1987] San Diego Law Review 24, $929-1002$ 
incentives to invest in socially desirable activity, such as e.g. the production of phamnaceuticals.

Landes and Posner also provide an example of this first case. ${ }^{16}$ Suppose that an enterprise, let us say a nuclear plant, wrongfullyy emits ionizing radiation into the environment, whereby it is established that an exposure of a certain population to this radiation may increase the number of cancer cases in the coming 20 years from 100 to 111 . Economic theory would hold that the enterprise would in that case not be held liable for the 100 cancer cases that would occur anyway (the so-called background risk), but only for the increased risk of the 11 additional cancer cases (the so-called excess risk). Hence, economics teach us that the injurer should only be held liable for the amount to which its activity contributed to an increase in the accident risk. ${ }^{17}$

The problem is obviously that we do not know which of the 11 persons has incurred the cancer as a result of the presence of the nuclear power plant. For every separate victim, the likelihood of incurring cancer as a result of radiation has been increased by approximately $10 \%$. If we now accepted that any of the 11.1 victims would be allowed to claim complete compensation of their damage from the injurer, this would not only be inefficient, but also unjust. It would indeed mean that, in 100 out of 111 cases, the injurer would have to pay compensation for damage which it never caused, but was caused by the background risk. Landles and Posner argue that in that particular case, if one disregards the administrative costs, the efficient solution would be the one in which each of the victims could only recover a proportion of their loss, equall to the excess risk caused by the activity of the injurer, from the injurer. ${ }^{18}$ In this case, that would amount to approximately $10 \%$ of the damage.

This shows that the first solution, simply arguing that in case of causal uncertainty the victims can claim full compensation, is inefficient and unjust. The same is obviously true for the second solution in which it would be required that the victim proves with $100 \%$ certainty that his damage has been caused by the tort. That requirement would mean that in many cases injurers would escape the clutches of the law whereas their activities have effectively created an additional risk. That solution would therefore amount to under-deterrence.

This therefore leads us to the two other solutions, often seen in tort law, being either the requirement that a certain threshold should be passed or the proportionate liability.

\section{Probability of Causation}

Before addressing the particular choice between those rulles, first it has to be stressed that the liability rule should, at least from an economic perspective,

If See W. Landes/R. Posner, Causation in tort law: an economic approach, [1983] Journat of Legat Siudtes (JLS), 109-134 and W. Landes/R. Posner, The economic siructwre of tor (1987). p. 242.

1: See M. Rizzo/F. Arnold. Causal apportionment in the law of torts: an economic theory, [1980] Columbia Law Rewiew 1410-1414 and M. RizzofF. Amold, Causal apportionnent: reply to the critics, [1986] JLS, 2:19-226.

W. Landes/R. Posner (supra note 16), p. 124. 
always be constructed in such a way that no liability is incurred for the socalled background risk (that already existed) but only for the excess risk which has been created by the activity of the injurer. ${ }^{18}$ Liability for the background risk would lead to spillage and is useless since the investments in the care of the injurer can never reduce the already existing background risk. The first issue the law has therefore to address is how the background risk can be eliminated; this can be done by establishing (on the basis of scientific evidence) to what extent the background risk has been increased by the injurer"s activity. ${ }^{21}$ Scientific evidence can then lead us to a number (expressed in a percentage) which indicates what the probability is that the injurer's activity caused the loss of the victim. This probabillity is referred to in the literature as the "probability of causation" and can be found by dividing the excess risk by the background risk + the excess risk. This so-called probability of causation formula has been used in radiobiology to establish the likelihood that $e . g$. an employee in a nuclear power plant contracted a cancer as a result of his work for the power plant. The American National Council on Radiation Protection and Measurements therefore launched, in a statement of 30 September 1992, a probability of causation method to establish whether a certain disease has been caused by radiation. ${ }^{22}$ On the basis of this method, the American National Institute of Health issued statistics that indicate what, given certain exposure doses and circumstances, the "probability of causation" will be.." These interesting examples from radiobiology show that, although it is scientifically not easy, it is not at all impossible to establish a probability that a specific amount of radiation may have caused a certain disease. The result of this will be that on the basis of this statistical evidence, a certain percentage will follow which represents the already mentioned "probability of causation". This then leads us to the question which of the last two legal solutions, threshold or proportionate liability is the most adequate to deal with causal uncertainty.

\section{Threshold Liability}

The threshold liability leads to a situation whereby the victim's claim is totally accepted if the probability passes the threshold of, say, $50 \%$. If the probability palsses the threshold, compensation is in full, but if the probability is lower than the threshold, the victim receives no compensation at all. The disadvantages of this hard and fast solution are obvious. One problem, both from the victim compensation as well as from the deterrence perspective, is that the probability of causation could systematically be lower than the threshold. Assume that the probability were systematically $40 \%$ that a certain cancer would

19. See L. Bergkamp, Liability and Environment (2001), pp. 287-289

${ }^{20}$ D. Rosenberg (supra note 12), 865-866.

So D. Kaye (supra note 13), $492-493$

${ }^{22}$ National Councill of Radiation, protection and measumement statements no. 7, 30 September 1992; see sulso V. Bond, The cancer risk attributable to radiation exposure: some practical problems, [1981] Health Physics, 108-111.

2. See on these tables also L. Ketchum, Epidemiologic tables. Law groundwork for future nadiogenic cancer claims, [1985] The Jowral of Nuclear Medicine, 967-972. 
have been caused as a result of a certain activity. If the threshold were $50 \%$ this would mean that the enterprise exposing persons to this $40 \%$ risk would systematically escape the clutches of the law. Victims would not be compensated and the incentives towards accident reduction would be too low. ${ }^{24}$ This seems inefficient and probably also unjust, since the enterprise has after all, in a number of cases, at least statistically, created certain losses. Assume that 100 cancer victims all file a lawsuit, in this particular example one would assume that 40 out of these 100 cancer cases would have been caused by the emissions emanating from the particular enterprise. However, for every individual the probability of causation would always be below the $50 \%$ threshold, so that the enterprise would not be held to compensate the victims in any of these cases. That is a clear disadvantage of this "all or nothing" approach which is inherent in the threshold liability.

\section{Proportionate Liability}

A more fine-tuned alternative can be found by translating the probability of causation by awarding the victim a proportionate amount of his damage. In practice, this would mean that if the probability that the victim"s damage was caused by the injurer's activity was $40 \%$, the victim would be compensated for $40 \%$ of his damage. From an economic perspective, the advantage of this proportionate liability is that it exposes the injurer precisely to the excess risk (in this case the additional number of cancer cases) that was caused by the (assumed wrongful) activity of the injurer. The enterprise will then, returning to the previous example, have to compensate $40 \%$ of all the damage of every particular victim, which amounts at the aggregate level to the same as compensating 40 out of 100 victims whose illness would have been caused by the enterprise. ${ }^{25}$

The result of this proportionate liability is that the injurer will receive optimal incentives for prevention, since he is precisely exposed to liability for the risk which was caused by his activity. ${ }^{26}$ A proportionate liability rule therefore provides optimal incentives for accident reduction, so it is generally held in the economic literature. ${ }^{27}$

\section{Nuances}

Obviously, a few nuances could be suggested concerning such a proportionate liability rule. One issue is the fact that we so far assumed that scientists are

S. Shavell (supra note 15$), 115$.

25 So S. Shavell (supra note 15 ), 116.

36 Soll Bergkamp (supra note 19), pp. 290-291.

27 See on this proportionate liability J. Makdisi, Proportional liability: a comprehensive rule to apportion tort damages based on probability, [1989] North Carolina Law Reitew, 1063; W. Landes/R. Posner, Tort law as a regulatory regime for catastrophic personal injuries, [1984] JLS, 417-34 and G. Robinson, Probabilistic causation and compensation for tortuous risk, [1985] JLS, 797-798. For a discussion of the possible legal foundations of a proportionate liability rule see A. J. Akkermans, Grondslagen voor proportionele ansprakelijkheid bij onzeker causaal werband, in W. H. wan Boom/C. E. C. Jansen/J. G. A. Linssen (eds.), Tuswen 'Altes' en "Niers'. Man toedeling naar verdeling wan nadee (1997), pp. 105-115. 
able to make some kind of assessment of the probability of causation. However, in reality it is often extremely difficult, even for scientists, to make an accurate assessment of probabilities that a certain activity may cause a certain damage. Some are therefore refusing this ,probability of causation" approach or consider it a lottery. It is certainly true that one may not expect too much of statistical evidence and scientists can also highly disagree on the potentially harmful effects of exposure to certain substances. However, these scientifie difficulties in assessing the probability of causation will also exist, no matter what type of approach one follows as regards causal uncertainty. In other words: the fact that one cannot always rely on the myth of scientific certainty should not be an argument $e . g$. in favor of an approach arguing that victims should always receive compensation of all injury, no matter what the probabillity of causation is. The choice between threshold or proportionate liability arises indeed from the moment scientists have come up with some figure indicating a percentage of probability. The question that then arises is how the law should deal with that percentage. My argument is that a proportionate approach is, in that case, a better answer than the all or nothing approach suggested by the threshold rule.

A second nuance concerns the fact that a proportionate liability rule may incur higher administrative costs than a threshold rule. A threshold rule rules out many liability claims, whereas in case of a proportionate liability rule, even the smallest probabillity could in theory lead to a claim. However, this argument of administrative costs could be an argument in favor of a threshold of e.g. $10 \%$ under which no compensation is paid at all and the application of a proportionate liability rule above that threshold. One could equally make the argument that in cases where the probability is e.g. $90 \%$, the proportionate approach could give way to an approach whereby the victim receives $100 \%$ compensation.

In sum, this proportionate liability rule has been defended by several American scholars and is also defended in the economic analysis of law. ${ }^{29}$ The negative consequences of causal uncertainty could then be limited. A proportionate liability rule is less rigorous than the all or nothing approach of the reversal of the burden of proof. ${ }^{30}$ The proportionate liability rule would indeed mean that all victims can claim a proportion of their damage equal to the amount by which the power plant contributed to the loss. Thus the exposure to liability of the enterprise corresponds precisely with the amount to which the

2is

See E. Estep fupra note 9y, 259-304. Very reluctant towards accepting statistical evidence in trials is also Tribe (ll. Tribe, Trial by mathematics: precision and ritual in the legal process, [1971] HLR, 1329-1393), who argues: "mathematical evidence is more misleading than laelpm fint"

29 D. Rosenberg (supra note 12), 851-929; S. Shavell (supra note 15), 587-609. Also the Duthly Attorney General Hartkamp dafended a market share hability in the DES case ([1992] THW

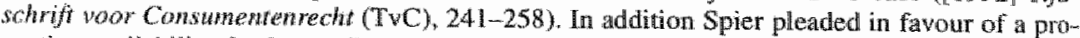

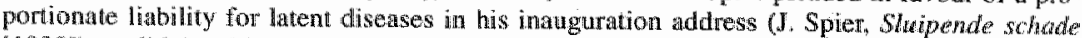
119901). dis A. Akkemons, (supra note 2) in his dissertation.

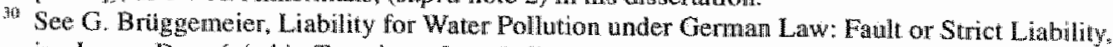
in: J. van Dumé (ed.). Thanboundary Pollution and Liability: the Case of the River Rlume (1991), Dap. 88-9). 
power plant contributed to the risk. This proportionate liability rule could, more particularly in cases of product liability, take the form of the market share liabillity. ${ }^{32}$

\section{Insurability}

Above, I argued that the tendency to bluntly shift the risk of causal uncertainty to enterprises may lead to inefficiencies and can be unfair. It is not hard to argue that such a shift of the risk of causal uncertainty, whereby injurers are held to compensate (at least partially) for damage which they have not caused, can also endanger the insurability. The simple reason is that the shifting of the risk of causal uncertainty to an enterprise means that the insurer of that particular enterprise (employer or producer) will be required to compensate for damage which, on the whole, had probably not been caused by the insured party. In that particular case, a liability insurer will have to cover for risks which the insured of that particular insurance company has not caused. ${ }^{33}$ As a consequence of that, an appropriate premium has not been claimed by the insurer, preventive measures bave not been taken and a reserve has not been set aside. Hence, such a shift of the risk of causal uncertainty may largely endanger insurability. ${ }^{3}$ Of course, one could argue that an insurer may well foresee the risk that judges or legislators shift the risk of causal uncertainty to enterprises and could thus require an appropriate premium to cope with this risk ex ante. However, this does not seem possible since it is hardly predictable to what extent judges will allocate background risks to particular enterprises. Moreover, such a shift of the risk of causal uncertainty can never lead to additional safety measures of the enterprise, since that enterprise can indeed not control the risks which are not caused by it. The shifting of the risk of causal uncertainty to an enterprise would mean that its insurer would not only have to cover the damage of its own insured party, but also the damage that might possibly have been caused by another party. This tendency is therefore highly problematic from an insurability point of view.

Again, the remedy from an insurability perspective seems clear, being the application of a proportionate liability rule. The proportionate liability rule signifies that the insured party is only held to compensate to the extent to which its activity contributed to the risk. That is, corresponding with the risk for which the insurer provided insurance coverage and which therefore corresponds with insurance principles. ${ }^{35}$ In sum, it is not difficult to argue that an unbalanced shift of the risk of causal uncertainty to enterprises may endanget

31 G. Robinson. Probabilistic causation and compensation for tortuous risk, $[1985]$ JLS, 798.

2. Sea also P. Widmer, Causation under Swiss Law, in: I. Spier (ed.), Unification of Tor Law: Causation (2000), pp. 112-113.

3) Sce T. Vanden Borre, Efficiente preventie en compensatie van catastroferisico "'. Her woorbeeld val schade doon kemongevallen (2001), pp. 543-545.

3. Also K. Abraham, Environmental Liability and the Limits of Insurance, [1988] Codwowbia Law Review 88, 959-960 and M. Katwnean, Pollution liability insurance and catastrophic environmental risk, [1988] Joumal of $R$ ist and Insurance (JRI). 89-90. See also L. Berglkamp, The Proper Scope of Joint and Several Liability, [2000] TMA, 154 mis5.

3. So L. Bergkamp (supra note 19), pp. 290-291. 
insurability and that, on the other hand, insurability may be improved by applying a proportionate liability rule.

\section{Joint and Several Liability}

\section{A. Examples}

As far as the examples of joint and several liability are concerned, we can be brief, since these are relatively well-known. The most feared example of a joint and several liability regime is probably the American environmental liability regime for soil clean-up under Cercla ${ }^{36}$, also known as the superfund regime. It is particularly the combination of a joint and several and retrospective Jiability under Cercla which is considered relatively harsh. ${ }^{37}$

But other countries have also developed joint and several liabilities, both within and outwith the area of environmental liability. Many systems accept that joint tortleasors are jointly liable for the damage. ${ }^{38}$

The working of a joint and several liability rule, although there can of course be differences between the legall systems, generally amounts to this: if it cannot be established which of the many tortfeasors contributed to a certain loss to a specific extent, all of them will be held jointly and severally liable. The effect is that the victim can choose to sue any of the injurers (who fall within the joint and several liability regime) and claim full compensation from any of them. The injurer, who had to fully compensate the victim, can then in turn reclaim from the other tortfeasors to the amount which they contributed to the loss. In this recourse action, the amount to which the individual tortfeasors contributed to the loss may then play a role again.

\section{B. Economic Analysis}

At first sight, a joint and several liability rule again appears as a regime whereby the legal system deviates from the principle that a tortfeasor should only be held liable for the damage which was caused by his own behavior. Under joint and several liability, the tortfeasor is held liable in full also for damage which was not caused by his own behaviour.

One could, therefore argue that a joint and several liability seems inefficient since it leads to over-deterrence: the injurer's liability is not limited to the risk created by his own activity. However, such a simple conclusion is (as usual) indeed too simple. One may argue that a distinction should be made between the situation of full solvency of all the contributing tortfeasors on the one hand and the situation in which either one or more of them are insolvent. ${ }^{39}$

36 This stands for the Comaprehensive Emironmertal Response, Compensation and Liability Act of 1980 .

37 For (critical) comments on this regime see the contributions in $\mathbb{R}$. L. Revest/R. B. Stewart (eds.), Analyzing Superfund. Economics, Science and Law (1995).

36. See in this respect the various contributions to J. Spier (supra note 1); Bergkamp considers it a comnon feature of many enwirommental liability regimes (L. Bergkamp [supra note 35], pp. 298-299).

\#) Also Widmer makes the point that joint and several liability anounts to at shifting of the risk of insolvency to the joint torteasors. See P. Widmer (supra note 32), pp. 112-113. 
In case of full solvency of all the actors, one can argue that there is no effciency loss caused by joint and several hability. ${ }^{40}$ In that case, the injurer who has to compensate the victim can in turn exencise a redress against the other parties who contributed to the loss in proportion to their contribution. Assuming that the other tortfeasors are fully solvent, the one who first paid merely pre-finances the compensation of the victim and will be able to recover a part of the damages paid. Thus, in the end, also under joint and several liability, the extent to which every contributor has to pay should be proportionate to their contribution to the risk. In that sense, a joint and several liability rule, com bined with a right of recourse and solvent actors amounts to a proportionate solution. The exposure to liability of every tortfeasor in this model is limited to his own contribution to the loss and thus optimal incentives would follow.

of course, one could wonder what the additional benefit is of a joint and several liability nule compared to the situation whereby the victim would have to ste every individual torfeasor separately. One could put forward a victin prom tection argument, simply on the basis of the fact that for the victim it is often more difficult to prove a causal link with the action of one particular actor. Thus it certainly makes the life of the victim easier if the victim can claim full compensation from one injurer who then has to exercise the right of redress against the other parties who contributed to the loss. However, in addition to this distributional argument, there are undoubtedly efficiency arguments in this particular case as well. They are probably not linked to a benefit in administrative costs. Indeed, whether the victim has to sue e.g. five different tortfeasors or the victim just sues one tortfeasor and the latter exercises a right of redress probably does not create much difference as far as the administrative costs are concerned. However, one could argue that the joint and several liability may give ex ante ex cellent incentives for mutual monitoring between potential joint tortfeasors. "Indeed, victims may well encounter difficulties in proving a causal link between the action of every particular tortfeasor and the loss he suffered. That may result in too few claims and hence in under-deterrence. Shifting the risk to the injurers would mean that they, ex ante, have an excellent incentive to mutually monitor their activities. Joint and several liability in fact shifts the risks of uncertainty concerming the proof of the causal link to the injurers. The victim need only sue just one of the many potentially liable injurers and claim full compensation. If the one injurer who is sued does not succeed in proving that others contributed to the loss, he will ultimately be liable for the damage incurted.

However, these arguments may not be walid any more under insolvency. ${ }^{42}$ Indeed, the picture changes if the torteasors are no longer solvent. In that

the For a detailled analysis of joint and sewerall liability when all defendants are tully solvert see $L$. Kombauser/R. Revese, Sharing damages among multiple tortfeasors, [1989] YLL, 831 884 and for the analysis in case of limited solvency see l. Komhatser/R. Revesz, Apportioning dam-

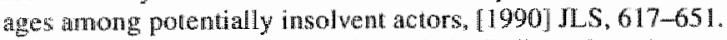

4i An argument in that direction is made by T. Therenberg (supra mote 5).

2. For an excellent analysis of the effects of various systems of extended liability see the recent puper by Boyd and lngherman who atgue that under certain conditions extended liability may promote cost internalization, but that there are serious draw backs as well Hence they argue

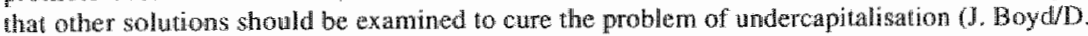


case, the risk of insolvency is shifted to the injurer who will be sued by the victim. If in that particular case one assumed that $e . g$. the victim sues only the solvent injurer and he has no right of recourse (given the insolvency of the others), the effect would be that one (solvent) injurer would be held to also compensate for losses which he has not caused. ${ }^{43}$ In case of insolvency, joint and several liability may thus violate the principle that the injurer should only be held liable to comperisate in the proportion to which he contributed to the loss. ${ }^{44}$

\section{Insurability}

From an insurance perspective, joint and several liability may be dangerous for the simple reason that the insurer is then no longer merely insuring the risk created by his individual insured (which he can still control), but also the risk caused by all the others. ${ }^{45}$. The welfare losses resulting from such a system of joint and several liability may be large. This mutual monitoring may ex ante not al ways be possible and the transactions costs involved (also in the systems of redress) can be huge. Hence, on balance it is doubtful that joint and several liability will have positive incentive effects. The insurance effect is obviously, as the case of causal uncertainty illustrated, that an insurer will be held liable for the risks that his insured never caused. Remember the example of the DES-case where the Dutch Supreme Court de facto applied a joint and several liability rule. This means that any victim can claim full compensation against any of the manufacturers. The insurer of the particular manufacturer then becomes de facto the insurer of the whole market. This tendency towards joint and several liability seems therefore to endanger the insurability. 46,47

Ungbergman, The Vertical Extension of Environmental Liability through Claims of Ownership, Contact and Supply, in: A. Heyes (ed,), The Law and Econontics of the Enwonment [2001], pp. $44-70$ ).

4h. Then joint and several liability would lead to over-deterrence, so Bergkamp rightly argues (L Bergkamp (supra note 19), p. 301 ).

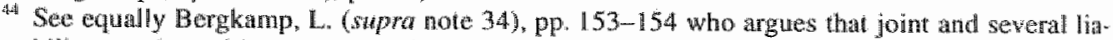
bility may be unfair and may lead to over-deterrence.

* See H. Cousy, Recent developments in environmental insurance, in: Abraham/K. Deketelaere/1. Stuyck (eds.). Recent Economic and Legal Developments in European Enwronmental Policy (1995). pp. 235-237.

44. A. Monti, Enwronmental Risk: A companative law and economics approach to liability and insurance, [2001] Eunopean Review of Private Law (ERPL), 51-79, 58. And see L. Bergkanu (swpra note 34 ), p. 154 who argues that under joint and several liability, civil hability becomes turpredictable and hence tninsurable.

W For an overview of the literature conceming the economics of joint and severall liability see $L$. Romhauser/R. Revesiz, Join and Several Liability, in: P. Newman (ed.), The New Palgrave Dichonary of Economics and the Law (1998), pp. $371-376$ and $\mathbb{L}$. Kornhauser/R. Rewesz, floint Tontfeasons, in: B. Bouckatr/G. De Giest (eds.), Encyclopedia of Law and Ecomomics, II, Chin Law and Economics (2000), pp. 625-643. 


\section{Channelling of Liability}

\section{A. Examples}

There is another feature that can be found in some liability statutes, mostly as a consequence of intermational conventions, where again a deviation can be found from the principle that only the injurer who caused the damage should be held fully liable for the loss. This concerns the so-called channelling of liability. Whereas with joint and several liability a victim can, in principle, claim full compensation from any of the multiple injurers, channelling is in fact the reverse: under channelling, the liability is attached to one party who becomes fully liable for the damage. This channelling, which means that the statute indicates which (of many possible) parties can be held liable for the loss, is often exclusive. The result is that the victim can only sue the ,channelled injurer" and not another party who might have contributed to the loss. Channelling can mostly be found in international conventions and, as a consequence, also in the implementing legislation. For instance, the conventions of Paris and Brussels of 29 July 1960 stipulate that only the licensee of a nuclear power plant is liable for damage caused by a nuclear accident. Although there is still some debate on the interpretation of the channelling as provided for in the conventions (more particularly it is debated whether there can still be a right of redress), many of the statutes which implemented the conventions stipulate that only the licensee of at nuclear power plant can be held liable for the damage caused by the nuclear accident. ${ }^{49}$ Some statutes therefore explicitly exclude claims of the victim against thind parties and stipulate moreover that the specific statutory regime is exclusive in the sense that it excludes the rights of the victim to use the ordinary mules of tort law. For instance, in the Netherlands as well as in Belgium the victim can no longer use tort law against the licensee of a nuclear power plant. In that sense the channelling in the nuclear liability regimes is 'exclusive'. Suits based on tort law are - at least in those regimes - no longer available to the victims. ${ }^{50}$

A similar regime can be found in the International Convention of Civil Liability for Oil Pollution Damage of Brussels of 29 November 1969, also known as the CLC Convention. The CLC Convention imposes (limited) hiability for the consequences of oil pollution damage on the tanker owner. Again, implementing legislation stipulates that this means that the liablity is chan nelled to the tanker owner and that liability suits either on other grounds against the tanker owner or against third parties are excluded.

Atticle 6 of the Paris Convention stipulates that the right of compensiation of the damage caused by a nuclear accident car only be exercised against the licensee who is liatbile on the basis of the Convention. Also the Vienna Convention of 1963 sipulates in Article 11.5 Except as otherwise provided in this Convention no person other than the operator shall be liable for muclear damage".

45 For a detailed discussion see the dissertation by T. Vanden Borre (supra note 33). pp. 251-268.

59. For Belgium see M. Farre/R. Van den Bergh, Liability for Nuclear Accident in Belgum from and Interest Group Perspectiwe, [1990] IRLE 10,241-254 and for the Netherlands, M. Faure, De verzekering van het mucleaire risico, in In volle verzekerdhetd (1993), pp. $247-260$.

3: For a discussion see C. Wu, La pollution du fair du rransport naritine des hydrocarbures. Responsabilité et Indemwisation des Dommages (1.994). 
Several other examples in international and national legislation of this $\$ y s-$ tem of "channelling" can be found. ${ }^{52}$

\section{B. Economic Analysis}

Several scholars, especially in the area of nuclear liability, have argued that this regime of channelling is inefficient from an economic perspective, at least if one believes that an exposure to liability provides incentives for prevention. It is particularly the aspect that channelling leads to the sole liability of the operator, with the exclusion of liability suits against third parties who have contributed to the Joss, which is criticized in the literature. ${ }^{5.3}$ Indeed, one can well imagine situations, for instance in nuclear accident cases where another party has contributed to the loss as well, for instance the one who may have delivered defective nuclear material that contributed to the loss. Exclusive channelling means that the victim no longer has the right to sue another party who could have influenced the accident risk as well. The effect is of course in the first place that the victim's claim may not be fully satisfied and hence one could criticize channelling from a distributive perspective. Moreover, the third party who has contributed to the loss should of course be exposed to liability in order to give him incentives for prevention. If the effect of the channelling is that the third party is no longer liable, this seems clearly inefficient.

Channelling may well have this effect, especially in the nuclear case since the liability of the licensee of the nuclear power plant (to which liability is channelled) is, moreover, also limited because financial caps are introduced on the compensation due to the victim. Hence, the effect of the combination of a financial cap with channelling is that the victim can exclusively sue the licensee of the power plant, where he is confronted with a financial cap. The victim has mo additional possibility to bring another law suit if, as a result of the cap, his damage were not fully compensated. A suit based on tort law against the licensee for the amount not covered by the cap is usually excluded in national statutes and a suit against a third liable party is usually excluded because of the channelling.

Of course, one could argue that the effect of reduced incentives might be limited because the licensee or operator who is held liable will still have the possibility of a right of recourse against the third liable party. In addition, it might be possible that he can pass on liability e.g. on the basis of contract. This may be the case if e.g. defective material were delivered to the licensee of a nuclear power plant. If such a shifting of the liability burden could take place, one could argue that the liability is simply transferred. Economists would, moreover, argue that such a re-allocation complies with the principles

${ }^{52}$ See "T. Vanden Borre, Kanalisatie in het debat betreffende de verzekerbaarheid wan een risico, (2001] Aansprakelijkheid, Verzekering en Schade (AV\&S), 175-177.

53 For a critical economic analysis of the channeling of nuclear liability see $T$. Vanden Borte, Transplantatie van 'kanalisatie van ausprakelijkheid' van het kemenergienecht daar het milieu (aansprakelijkheids)recht: cen goede of een gebrekkige zaak?, in: M. Faure/K. Deketelacte (eds.), Ins Conmune en Milieuredu, Actuatia in het Milientrecht in België en Nederland (1997), pp. $329-382$ and T. Vanden Borre (supra note 33), pp. 693-701. 
of the Coase theorem. ${ }^{54}$ Indeed, in that case, one could argue that to the extent to which the ones who actually contributed to the loss are still held liable, an efficient allocation of resources nevertheless took place. However, this private re-allocation of liability may not always be possible and some of the conventions, moreover, even restrict the possibilities of a right of recourse. Channelling can hence hardly be considered as an efficient mechanism for the prevention of accidents nor as an optimal tool for victim compensation.

The argument which is sometimes used to defend channelling, is that it makes the life of the victim so much easier since the will no longer have to investigate who precisely the liable injurer is (in case of an accident with multiple injurers). The statute indeed simplifies the life of the victim by indicating that he can only sue the injurer to which liability is channelled. Thus, one could recognize an argument that channelling would. lead to a reduction of transaction costs ${ }^{55}$ However, this seems hardly walid: the additional benefit of channelling for the victim is limited (the costs of finding out that it is e.g. the licensee of a nuclear power plant who may be primarily liable are not that high), whereas the disadvantages for the victim are huge (he no longer has the possibility to claim his damage from other parties who may have contributed to the loss as well). From a victim's perspective, one may well argue that the rulle we discussed above, joint and several liability, is of course preferable: in that case, the victim can simply sue any of the available injurers and claim full compensation.

The reality is probably that channelling was not introduced to defend the interests of the victim, but the interests of industry. In a recent dissertation, Var den Borre powerfully demonstrated that channelling was introduced in the nuclear liability conventions on the request of American suppliers of nuclear fuel. This legal technique was needed to assure them that liability suits would never be brought against them but exclusively against the (European) operators of the power plants. ${ }^{56}$ Channelling is therefore probably merely an instrument of interest group politics rather than an efficient legal technique to promote the optimal working of accident law.

\section{Insurability}

When discussing joint and several \iability, we argued that a major disadvantage of that regime is that one injurer (and therefore his liability insurer) may be held to compensate not only for the loss caused by that injurer, but also for the loss caused by others. Some may therefore argue that channelling, which is in fact the reverse of joint and several liability, should be an ideal system from an insurability perspective: at least now it is clear that a suit can only be brought against one actor, which would make the life of liability insurers much easier. Indeed, some have argued that channelling is useful since it can improve the insurability of risks. Especially in the nuclear contexts it has been argued that channelling of nuclear liability has the advantage that only the lic-

54 See M. Trebilcock/R. Winter, The economics of nuclear accident law, [1997] IRLE, 232-235.

5.5 See T. Vanden Borre (supra note 33), pp. 698-699.

See T. Vanden Borre (supra note 33), pp. 237-250. 
ensee of a nuclear power plant would have to take out insurance coverage." Also the chamnelling in oll pollution cases is defended by arguing that it would reduce insurance costs. The argument is simply that, with chanelling only the tanker owner (and no other parties) would have to take out insurance coverage. "This insurance argument is, however, rather simplistic and even wrong." Assume that parties other than the licensee of the nuclear plant or the canker owner would be held liable; they could in that case obviously purchase liability insurance as well and, if liability rules were applied correctly, their exposure to liability would be limited to the extent to which they contributed to the loss. In other words: if each and every party is held separately (proportionally) liable for its own contribution to the risk, liability insurance is possible as well and an inefficient regime such as channelling does not have to be used to increase insurability. Indeed: the mere fact that without channelling several potentially liable parties will take out insurance coverage does not mean that total insurance costs will rise. ${ }^{60}$

Exclusive channelling may even have disadwantages for the liability insurer of the channelled operator. Indeed, he may also have to cover accidents in cases where the loss was not caused by his insured, but where the damage is only allocated to the channelled operator because of the channelling regime. Since channelling does not provide adequate incentives to other parties who contributed to the loss, channelling can even increase the liability exposure for the liability insurer. Channelling thus creates a greater risk exposure for the operator and therefore a higher uncertainty for the insurer. If channelling has therefore any effect on the insurability, it is more likely that it decreases insurability rather than that making liabillty better insurable.

\section{Concluding Remarks}

In this contribution to honour Pierre Widmer I have looked at a number of seemingly different situations; casual uncertainty, joint and several liability and channelling and looked at the impact of these issues on insurance. At first sight it concems three totally different situations, but there nevertheless seems to be one issue which they have in common. In all of these situations there is a risk that the injurer might be held to compensate more than the damage that he has caused. I applied some simple economic analysis of law, which provides the basic insight that those situations might lead to inefficiency in so far as they do indeed hold an injurer to also compensate for damage which was never caused by his activity. Economists would generally claim that these situmations are inefficient because there is a risk of over-detertence. However, eco-

${ }^{57}$ See $\mathrm{H}$. Cousy, Een nieuwe vorm van schuldoze ansprakelijkheid voor schade veroorzatak door het vreedzawn gebruik wan kemenergie, [1974-1975] Jura Falconis, 46.

3. See A. Popp, Liability and compensation for pollution damage caused by ships revisited report on an international conference, [1985] Loyds Moritume and Commercial Law Quamerty 120.

\$2 So T. Vanden Borre (supra note 53), pp. 366-367 and T. Vanden Borre (suppra note 33 , pp. 695-697 and T: Vanden Borre (supra note 52). pp. $180-182$.

tall See T. Vanden Borte (supro note 33), p. 696. 
nomic analysis seemed to provide more nuanced answers than that. In some cases such a deviation of the rule that the injurer should only be held liable for the losses that he actually caused should not necessarily lead to inefficiencies. For instance, in the case of channelling, the fact that victims can only claim compensation from one designated injurer may give him in tum incentives towards additional control of other parties who could have contributed to the risk. A joint and several liability rule might also have the effect of an increased mutual monitoring between joint torteasors. However, all of this assumes that all these potential injurers are indeed solvent and that they can thus be held to compensate to the amount in which they contribute to the risk, e.g. via a right of redress.

It was shown that these deviations from the basic rule that the injurer should only be held liable for the damage that was caused through his activity may also cause problems at the insurance level. The reasoning is again straightforwand: if an insurer is not only held to compensate for losses actually caused by his injuner, but also for losses caused by others, it will neither be possible to calculate an accurate premium nor will it be possible to take appropriate preventive measures or to calculate the amount of the reserve that should be sef aside. The remedy which is proposed by the economic analysis of law to increase efficiency and to guarantee insurability seems to be the same: a proporfionate approach would, e.g. in the case of casual uncertainty expose the injurer merely to the risk that he actually caused. A proportionate approach would also result in a rejection of joint and several liability and limit the liability of the injurer to the losses actually caused by him. Strangely enough, channelling of liability has been defended because it would increase the possibilities of uninsurability, whereas it was argued in this contribution that the opposite might be true. Channelling might decrease rather than increase insurability and might moreover have an adverse affect on incentives for prevention. Thus it should not be surprising that economists generally favour a proportionate approach which, again, might also increase insurability. However, several examples were provided to show that in many cases this proportionate approach is not followed and that thus injurers are held liable for damage that they could never have caused. Apparently insurers do cover (or at least partially) these risks, so thatt some may argue that apparently there is no uninsurability. That is, however, a too simplistic approach. Indeed, when insurers today are held to cover also for losses not created by their insured this may, for instance, in a case of joint and several liability lead in the end to a withdrawing of insurers from liability insurance markets. In some areas that already seems indeed to be the case. However, one could well make the argument that also a system where injurers are a]so held liable for risks created by others (e.g. under joint and several liabil ity) could be insurable, under the condition that it is known ex ante for an insurer that such a system would exist. Then, in theory, the insurer could foresee this and take it into account when calculating the appropriate premium. However, that aspect might be particularly difficult since it can be hard for an insurer to predict for what other losses his insured might be held to compensate as well. But, in theory, the probability that his insured would be exposed to risks not created by him as well could be taken into account and an appropri- 
ate risk premium could be demanded by an insurer. The question will abviously arise whether in practice there will be a willingness to pay for this increased premium and, again, it is highly doubtful whether such a solution is efficient.

Of course I do realise that the analysis provided in this contribution is far from complete. In practice the refinements in legal doctrine or case law, e.g. concerning the way to deal with causal uncertainty, could not be discussed. Moreover, I also do realise that to some extent this contribution approached the problem rather one-sidedly from the deterrence and insurability perspective. From these perspectives it is relatively easy to argue that legal constructions, such as the one discussed in this contribution, on the basis of which insurers are held to compensate for losses other than the ones they caused themselves, are inefficient. However, that does not mean that this should also be guiding at the normative level. Indeed, from a distributional perspective one may well come to another conclusion. Indeed: if one believes that liability rules do have a deterrent effect, it can be rellatively simply argued that it makes no sense to hold an injurer liable for losses other than the ones that he caused himself. Thus on that ground e.g. joint and several liability could easily be rejected. However, from the victim's perspective, that would obviously mean that the victim would have to bring a law suit against all of the various contributors to the risk. and that the effects of the insolvency of one would be left with the victim. Hence, some may well argue that since tort law also has a compensation goal, from a distributional perspective a joint and several liability rule is preferable. Indeed, it is probably mainly the victim compensation concern that leads legislators and judges to introduce e.g. joint and several liability or to shift the risk of causal uncertainty to enterprises rather than to victims. From a victim compensation perspective, proportionate solutions that can be defended on efficiency grounds, are obviously less desirable. However, it would allso be rather naive to mainly follow the other perspective and hence to argue that the legal issues dealt with in this contribution should always be shaped in such a way that they provide an optimal guarantee for the victim that he will receive full compensation, no matter whether that particular defendant did indeed completely cause the loss. A right balance will have to be struck here between, on the one hand, insurability demands and, on the other hand, demands of victim compensation. Indeed, a tendency whereby attention would merely be given to the victim compensation aspect, neglecting the effects on insurability could in the end precisely have the adverse effect that insurability would no longer be available and that thus victim compensation in the future would be endangered. Hence, it should never be forgotten that the desire to shape tort law in such a way that its insurability can be guaranteed is, in the long term, in the interest of injurers and victims. 